XIV Российская национальная конференция по сейсмостойкому строительству и сейсмическому районированию (с международным участием). Сборник материалов

УДК 699.8

DOI 10.37153/2687-0045-2021-14-48-48

Секциия 3

Конструкиии сейсмостойких зданий, основания и фундаменты

\title{
ОЦЕНКА СЕЙСМОСТОЙКОСТИ НЕНЕСУЩИХ КОНСТРУКЦИЙ И ОБОРУДОВАНИЯ НА ОСНОВЕ ЛОКАЛЬНОГО КОЭФФИЦИЕНТА ДИНАМИЧНОСТИ
}

\author{
Кабанцев О.В., Смирнов В.А. \\ НИУ МГСУ
}

Представлен анализ методов оценки сейсмостойкости ненесущих конструкций. Показано, что реальные механизмы работы элементов, не входящих в состав несущей системы, не учитываются существующими методами расчета. В рамках физических экспериментов исследованы действительные механизмы работы ненесущих конструкций при динамических воздействиях, соответствующих сейсмическим. Разработан метод получения индивидуальных величин коэффициентов динамичности различных видов ненесущих конструкций, представляющих собой локальные коэффициенты динамичности таких конструктивных элементов. Предложен и обоснован метод оценки сейсмостойкости ненесущих конструкций на основе учета действительных локальных коэффициентов динамичности и величин переносных ускорений несущей системы в зонах установки ненесущих конструкций. 